Article

\title{
Useful Knowledge and Beautiful Knowledge in Dewey and Thoreau
}

\author{
Naoko Saito \\ Graduate School of Education, Kyoto University, Yoshida-Honmachi, Sakyo-ku, Kyoto-shi, Kyoto 606-8501, \\ Japan; saito.naoko.6v@kyoto-u.ac.jp
}

Academic Editors: Paul Standish and SunInn Yun

Received: 19 December 2016; Accepted: 15 May 2017; Published: 4 June 2017

\begin{abstract}
In order to see how the wisdom of American pragmatism can be usefully used in response to the crisis of humanities and of democracy and education, the purpose of this paper is to explore elements in Dewey's thoughts that tend to be hidden in its familiar mainstream reception. The threads of these ideas are evident in Democracy and Education, but they become woven into more explicit expression in Dewey's later work, particularly in Art as Experience. Following these threads makes it possible to reveal ways of thinking about Dewey's pragmatism and education that take it beyond its limitations. Those limitations are to be understood in terms of a restricted account of problem-solving, instrumentalism, unqualified aversion to skepticism, and the absence of a tragic sense. Yet a greater sensitivity to these matters is there recessively in Dewey's writings, and the reading of his work contrapuntally with aspects of Thoreau's, helps to bring these to light. It is through such a reading that the potential of Dewey's work as a response to the pressures of a globalized economy come to be seen.
\end{abstract}

Keywords: antifoundationalism; Beautiful Knowledge; Cavell; criticism of criticisms; Dewey; Emerson; global economy; pragmatism; problem-solving; useful knowledge; Thoreau

The problem of the educator is to engage pupils in these [occupational] activities in such ways that while manual skill and technical efficiency are gained and immediate satisfaction found in the work, together with preparation for later usefulness, these things shall be subordinated to education-that is, to intellectual results and the forming of a socialized disposition. What does this principle signify?

-John Dewey, Democarcy and Education [1] (p. 204)

\section{Introduction: The Crisis of the Humanities in Higher Education}

It is now commonplace that the humanities are in crisis. Against the background of the worldwide trend towards STEM (Science, Technology, Engineering, and Mathematics) funding in higher education, the humanities are perceived to be "useless." In Excellent Sheep (2014), William Deresiewicz illustrates this situation in the elite universities in America: the university is no longer the place for a liberal arts education, the place to "help you acquire a self, or develop an independent mind, or find your way in the world" [2] (p. 1). In the credentialism of a "narrow practicality", "the purpose of life becomes the accumulation of gold stars" [2] (p. 16). Education is an investment in one's life, and it is an investment from which society understandably expects a pay-off. Hence, the current university cannot offer the space for education for "the inner freedom" [2] (p. 25), with the concomitant result that there is "a violent aversion to risk" [2] (p. 22) "Polite, pleasant, mild, and presentable; well-mannered, well-groomed, and well-spoken. [today's students] have fashioned the façade of happy, healthy, high achievement" [2] (p. 12): young students in elite universities have become "excellent sheep" [2] (p. 2), blindly following where they are led. The mentalities of closed-mindedness, of an inward-turning 
(domesticated) tendency, of the avoidance of risk, of conformity to the existing system, and of lack of critical thinking are not only the crisis of humanities: more generally, there is a crisis of democracy as a way of life, as John Dewey anticipated in 1939 [3]. Philosophy is one of its casualties, perceived to be "useless", of course.

However, what is useful knowledge for human beings? What might be the task of philosophy in service of life? These are the focal questions Dewey addresses in Democracy and Education (1916). Since Dewey's time, these questions have gained new importance. While the language of education is oriented towards practical use and problem-solving, these ideas themselves-use, practicality, activity, and life-have been diminished to economic need. So is democracy. Although the apparently humane language of education echoes Deweyan ideas of ever-continuing growth and self-realization, the ideal of the human being is envisioned in terms of human resources for economic growth. More than ever today there is a need to present an alternative sense of useful knowledge. What should be resisted is the assimilation of the idea of use into the dominant discourse of profit, efficiency, and transparency. Now is the time to reconsider an alternative conception of philosophy and education, to rethink the meaning of thinking in life, and to rethink the role of the humanities in terms of an education for a higher sense of practice. What kind of place should a university be if it is to be in service of democracy as a way of life?

In response to the challenge of our times, this paper reconsiders the significance of Democracy and Education today, in particular, in terms of what Richard Bernstein calls the "global resurgence of pragmatism" [4]. It is pragmatism-in particular, Dewey's idea of democracy and education-that already, one hundred years ago, had the insight to criticize prevailing notions of useful knowledge and to raise in a new way the question of economy. Dewey's pragmatism, philosophy for praxis, needs to be reconstructed and taken beyond its limits. I take those limits to be tendencies in Dewey's writings that become consolidated in the mainstream of interpretation. They include a restricted account of problem-solving, instrumentalism, unqualified aversion to skepticism, and, so it has been argued, the absence of a tragic sense. Such a reconstruction has the potential to convert our ways of thinking about education, beyond the dichotomy of the useful and the useless, and to resuscitate philosophy for life: thence, we might live within an economic system yet without being assimilated into a narrow, utilitarian sense of economy. Dewey's pragmatism redirects us to a higher sense of practice, finding in the humanities a means to rethink the meaning of practicality and usefulness.

In the following, and in order to see how the wisdom of American pragmatism can be usefully used in response to the crisis of humanities and of democracy and education today, I shall, first, discuss the "global resurgence of pragmatism", based upon Bernstein's work. Some philosophical features of pragmatism centering on the concept of praxis will be explored as key features of American philosophy, showing how they are relevant to the issue of useful knowledge today, and how pragmatism has a potential to function as a critical force. The use of Dewey's pragmatism, then, will be illustrated by Democracy and Education with a particular focus on his idea of overcoming the dichotomies between work and leisure, between the humanities and the sciences, and between vocational and intellectual education.

Second, I shall explore a dimension in Dewey's philosophy of thinking beyond problem solving. The limitation I have in mind here has to do with the narrow terms in which this is understood, specifically in terms of its implication that there is a clearly identifiable problem that stands in need of, more or less, a technical solution. In due course, this will connect Dewey's anti foundationalism and his idea of betweenness with notions of the obscure and twilight, the sense of this will be explicated. Further, to enhance this dimension of thinking beyond problem solving, I shall shift attention from Democracy and Education to his later work, Art as Experience (1934) [5]. Dewey's later writings on aesthetics bring to light an alternative sense of useful knowledge-knowledge that cannot be simply assimilated into the practical or reduced to the accountable, to the terms of empirical evidence. Here, I shall foreground Dewey's insightful idea of the inseparability of the functional and the beautiful-a suggestion of which is already there in Democracy and Education. Going beyond the dichotomy of the 
beautiful and the sublime, and between the aesthetic and the functional (the instrumental), Dewey's pragmatism implies, even if only recessively, transcendence as rebirth in the ordinary, through high intelligence in the low and the common.

This line through Dewey, with its threads in Democracy and Education, can be taken up by reading his work contrapuntally with that of Thoreau's, whose idea of Beautiful Knowledge evokes a conception of useful knowledge that integrates language, thought, and the body in life as a whole [6] I shall conclude that the economy of Beautiful Knowledge is a way to make the best use of the wisdom of Dewey's pragmatism and, more generally, of American philosophy in resistance to the tide of the global economy.

\section{The "Global Resurgence of Pragmatism" and the Real Use of Democracy and Education Today}

\section{1. "The Global Resurgence of Pragmatism"}

It is pragmatism, the philosophy of praxis, that redirects us in our thinking about education within the globalized economy. There has been a resurgence of interest in pragmatism recently, especially in the centennial year of Dewey's Democracy and Education. In a special issue of Educational Philosophy and Theory, entitled "Dewey's Democracy and Education in an Era of Globalization", Mordechai Gordon and Andrea English connect globalization with "the marketization of education, the increase in digital technologies between teachers and students, and data-driven decision-making at all levels of education" [7] (p. 977). However, though many of the articles of the volume are helpful to reconsider the value of Dewey's Democracy and Education, its general tone, when it comes to the use of Dewey's pragmatism, is to accept what Dewey says, and then to apply this to the practice of education, in terms of "educational implications." I do not wish to deny the importance of the application of theory to practice. My purpose rather is to show the real use of Dewey's pragmatism—which requires the critical analysis of what he says and how he says it, and the elucidation of its limits.

It is significant, then, that Richard Bernstein calls for a global resurgence of pragmatism that emphasizes philosophical analysis before application and, thus, helps us elucidate both the rich potential and a different "global" horizon, as it were, within Dewey's thoughts, the way towards a higher sense of praxis. In 1992, Bernstein published an article entitled, "The Resurgence of Pragmatism", which was a neutral, well-balanced, and objective appreciation of pragmatism, of its development and ramifications in the 20th century, and of its revival in the 1990's. It was underpinned by the author's unflagging insistence on the "persistence and continuity of the pragmatic legacy" ([4] (p. 13); [8] (p. 818))—stressing in particular its worldview of chance and contingency, its fallibilistic and experimental spirit, and its negation of fixed foundations. At the same time, in his way of "retelling" the story of pragmatism, Bernstein adroitly demonstrated that pragmatism's "permanent legacy" or "continuity" had a kind of permanence, through which the substance of its wisdom was continually exposed to a retelling, to criticism, and reconstruction in the particular context of particular times. Twenty-four years later, in "The Global Resurgence of Pragmatism" [9], Bernstein has demonstrated its unflagging power, emphasizing that "[t]here is more vital and creative discussion of pragmatism" than there has been for some time [9].

There are some distinctive dimensions of the global resurgence of pragmatism. First, is the multivocalnature of pragmatism. "[T]he story", as Bernstein says, is "one of continuity" [9] produced in ensemble and in disharmony, in the "plurality of multiple voices" [9]. Second, is what might be called the power of marginal voices. Though classical pragmatism has been from time to time marginalized, especially with the dominance of analytical philosophy, he points out that "American pragmatism no longer looks like a marginal provincial movement that can be bracketed and dismissed" [9]. The dynamic movement of pragmatism is constituted by an apparently paradoxical relationship between center and periphery, and between continuity and discontinuity. Pragmatism is a philosophy that makes of such apparent paradox as its own source of development. Third, is its power of crossing boundaries. As a philosophy for life, as an American philosophy, pragmatism has the drive to go 
"beyond the boundaries of academic philosophy departments" [8] (p. 817), and even beyond its own Americanness-as is most distinctively shown in Habermas's and Honneth's appreciation of pragmatism in critical philosophy, and Gadamer's hermeneutics in the German tradition ([4] (pp. 15, 23-25, 29, 85-87); [9]), and even, to its relation to Asia [10]. If there is any "permanent" value to pragmatism, it is in its malleability, its capacity to unsettle fixed and stable points of view, in spite of the fact that this makes it liable to be misunderstood. Fourth, is what might be called the perfectionist and affirmative thrust of pragmatism. It is derived from its acknowledgement of contingency: it is a philosophy in response to human finitude. Such a perfectionist, affirmative drive is underpinned by its humanitarian faith, its commitment to "furthering genuine human emancipation" [9]. This is something that pragmatism makes possible in its "antiskeptical nonfoundational fallibilism" [9]. To think without fixed ground does not mean that anything goes. This is an idea of perfection without final perfectibility, without abrogating the quest for a better life. As Dewey himself expresses this poignantly, "Perfection means perfecting, fulfillment, fulfilling, and the good is now or never" [11] (p. 200, my italics). With these insights, pragmatism is "not passé but actually ahead of their time" [9] (my italics). The power of its resurgence hinges on its own power of "self-criticism", as Dewey says, a power that enables it and us to cross boundaries, beyond division and dualisms.

Bernstein's retelling of the global resurgence of pragmatism can be further recounted in response to the question concerning useful knowledge, democracy, and education. He himself does not specifically talk about "education", or for that matter, how the aforementioned features can be "applied" to the practice of education in a kind of globalization as specified by Gordon and English. He does, however, discuss education in a broader sense in reference to Plato's understanding of education and to Hegel's idea of Bildung. For Dewey, as Bernstein says, "philosophy can be characterized as the general theory of education" [9]. In other words, education is internal to pragmatism; praxis, inseparable from education. Education here implies critical function in Dewey's idea of "democracy as a way of life" and the criticism of the "professionalization" of philosophy [9]. As praxis is a task, so too is education and creative democracy [4] (p. 88). In this task, dichotomies are to be overcome from the perspective of life as a whole. We cannot help but live the life of contingency, especially in times of "crisis, anxiety, a fear" [4] (p. 30).

In the recognition of the "fragility of dialogical community" [12] and fallibilism (which Bernstein refers to as pragmatism's "dialogical, fallibilistic orientation" [4] (p. 30), democracy and education require "genuine dialogue" in "serious encounter with the other" [12], "an open-ended conversation with many loose ends and tangents" [4] (p. 31). In Bernstein's recounting of the global resurgence of pragmatism, the use of a vocabulary of "instrumentalism", "experimentalism" [4] (p. 11), and "problem solving" to characterize Dewey's pragmatism, and the idea of "cash value" associated with William James open new points of entry into Democracy and Education.

\subsection{From Bernstein to Dewey: Democracy and Education Revisited}

Bernstein is "concerned with what we may still learn from Dewey in our own attempts to understand and foster democratic practices" [4] (p. 71). In response to the question, "What is useful knowledge?" Democracy and Education is a book that gives us some practical wisdom. First and foremost, Dewey does not negate or avoid the idea of use, and takes a stance that it is an ingredient of human experience: "practice falls of necessity within experience. Doing proceeds from needs and aims at change" [1] (p. 274). In the opposition of "experience and true knowledge" [1] (p. 271), Dewey reclaims "knowledge of how to do" [1] (p. 192, my italics): it is the philosophy of the how, in service to the "problems of men" [13]. With regard to informational knowledge, he says: "Knowledge', in the sense of information, means the working capital, the indispensable resources, of further inquiry; of finding out, or learning, more things. Frequently it is treated as an end itself" [1] (p. 165). However, information should be used as a means of inquiry [1] (p. 196). Such knowledge is a medium through which mind goes through a "passage from doubt to discovery" [1]: it is "experimental" [1] (p. 197). 
Second, experimentalism is crucially related to Dewey's overcoming of the mind-body dualism which is reflected on and illustrated by his idea of labor. "The laboratory is a discovery of the conditions under which labor may become intellectually fruitful and not merely externally productive" [1] (p. 284). Such notion of labor is crucially related to Dewey's well known idea of "occupations" in schools [1] (p. 317). In opposition to the dichotomy of paly and work, and of activities and intellectual studies, Dewey writes as follows:

The problem of the educator is to engage pupils in these activities [as outdoor excursions, gardening, cooking, sewing, printing, book-binding, weaving, painting, drawing, singing, dramatization, story-telling, reading and writing, etc.] in such ways that while manual skill and technical efficiency are gained and immediate satisfaction found in the work, together with preparation for later usefulness, these things shall be subordinated to education-that is, to intellectual results and the forming of a socialized disposition [1] (p. 204).

The more human the purpose, or the more it approximates the ends which appeal in daily experience, the more real the knowledge [1] (p. 206).

Dewey here italicizes the word "education" to signify that "usefulness" should have humane purpose in service to human growth. At the same time, such idealism should be grounded on the reality of human and humane experience.

This then guides us to Dewey's view on humanities in the curriculum. The below is his definition of the humanities:

With respect then to both humanistic and naturalistic studies, education should take its departure from this close interdependence. It should aim not at keeping science as a study of nature apart from literature as a record of human interests, but at cross-fertilizing both the natural sciences and the various human disciplines such as history, literature, economics, and politics [1] (p. 294).

Interdisciplinary in nature, then, humanistic studies should not be taught as "isolated subjects" but should be connected with the pupils' experience [1] (p. 295). Democracy and Education, thus, is a book that enables us to rethink the future of humanities, or to put it in more Deweyan terms, on human science. What he means by "humane study" is not geared towards aristocratic liberal arts: rather humanistic studies involve the more down-to-earth, daily experiences of human beings.

Third, Dewey's non-dualistic idea of human science points us to a way beyond the dichotomy of natural science and human studies, of practical studies (including manual labors) and intellectual studies, and of the high and the low. On a more practical level, it points us to a kind of integrated notion of vocational education and liberal arts studies. When Dewey says, "The dominant vocation of all human beings at all times is living_intellectual and moral growth" [1] (p. 320), he implies in the term "vocation" the practical sense of job as well as a more moral sense of a mission assigned to humans. Literary training should not be separated from the idea of usefulness. Dewey is, in particular, critical of the idea of "literary callings" as "non-vocational", as the highbrow studies.

$[\mathrm{M}]$ any a teacher and author writes and argues in behalf of a cultural and humane education against the encroachments of a specialized practical education, without recognizing that his own education, which he calls liberal, has been mainly training for his particular calling [1] (p. 322).

Liberal arts should not only be integrated studies with natural sciences: they also should be integrated with vocational studies in its focus on experiment, use, and practical ends [1] (p. 269). This is the wisdom of non-elitist American philosophy.

Fourth, such an integrated notion of liberal arts and humanities is inseparable from his idea of creative democracy. Democracy is in service to the liberty and liberation of the human mind. It calls for 
the kind of freedom that is different from freedom in neoliberalism. Though he does not avoid "cash value" of economy or the idea of usefulness, Dewey reminds us that, as a "moral ideal", democracy as a way of life takes precedence to the priorities of a neoliberal economy. Knowledge is instrumental to education. Economy is the means of education. Human beings are educated within and by economy [1] (p. 325).

In Democracy and Education, Dewey presents an antifoudnationalist notion of growth-“education is all one with growing; it has no end beyond itself" [1] (p. 58). With their anticipation of the dangers of a globalized economy and of the threat to the humanities, the aforementioned four features of Democracy and Education helps us reconsider the fact that possibilities for human growth are entwined with questions of economy [1] (p. 208). Growth, however, cannot simply be equated with economic growth for monetary or utilitarian purposes [1] (p. 327). Thinking beyond dualisms (of mind/body, means/ends, and fact/value [1] (p. 269), thinking in terms of life as a whole, is at the heart of the philosophy of praxis. It bridges "culture and utility" [1]. It integrates reason and emotion and "the political and the psychological":

The two distinctions, psychological and political, translated into educational terms, effected a division between a liberal education, having to do with the self sufficing life of leisure devoted to knowing for its own sake, and a useful, practical training for mechanical occupations, devoid of intellectual and aesthetic content [1] (p. 270).

This envisions an alternative conception of education-"a change in the quality of mental disposition-an educative change" [1] (p. 326). We might call this growth human transformation in service to life as a whole. Education in this broad sense is not to be assimilated into the existing currency of the economy, but, instead, functions as its critical force. Thinking through praxis does not allow us to loosen the grip of thinking: rather, thinking in life requires of us rigorous thinking: "Intellectual responsibility means severe standards in this regard. These standards can be built up only through practice in following up and acting upon the meaning of what is acquired" [1] (p. 186).

In Dewey's pragmatism, the idea of useful knowledge is inseparable from problem-solving as a mode of thinking [1] (p. 157). "Only by wrestling with the conditions of the problem at first hand, seeking and finding its own way out, does he think" [1] (p. 167).“Thinking is the method of intelligent learning" [1] (p. 159). Dewey, however, suggests another dimension of problem solving, "Inference is always an invasion of the unknown, a leap from the known" [1] (p. 165). Thinking is adventurous, which suggests, most obviously, the making of forays into the unknown but also, no less significantly, the advent of thought, a waiting or readiness for its arrival. His experimentalism has an existential depth of the philosophy of chance, to transcend borders beyond existing knowledge [14]. Hence, at the heart of humanities, there is a need for criticism and the cultivation of what, in "The American Scholar", Emerson calls "Man Thinking" [15] (p. 52). In using this capitalized phrase, Emerson has in mind not that degenerate product of schooling that is manifested in the "mere thinker" who becomes "the parrot of other men's thinking" but rather an actualization of thought that can both draw on the past and orient itself towards the future. Moreover, Emerson is not concerned narrowly with a kind of academic life but with what it is to be a human being. The thoughts here resonate with Dewey what will later call for as the development of a "courageous intelligence", a kind of intelligence "practical and executive" [1] (p. 329). It chimes with that facet of Dewey's pragmatism that Hilary Putnam identifies with Dewey's "criticism of criticisms" ([16] (p. 298); [17] (p. 96)) and which is rightly seen as a precondition of problem solving and as a key to creative democracy [18] (p. 143).

\section{Thinking beyond Problem-Solving: From Democracy and Education to Art as Experience}

\subsection{Twilight Zone of Inquiry}

In order, however, to further reinforce for today the rich potential entailed in Dewey's pragmatism, to make best use of the wisdom of Democracy and Education with its higher sense of use and practice, and to realize human science as Dewey envisioned a hundred years ago, we need to critically reexamine 
how its real use is made possible in the contemporary context. The tide of the globalized economy concomitant to a drive towards empiricism and transparency is much stronger today than in Dewey's time. Education can easily be assimilated into apparently stable, foundationalist discourse. The trend towards prioritizing STEM funding is a real threat to the humanities in higher education, accentuating narrow and superficial, and lazy, conceptions of use and utility. By contrast, thinking on the way is difficult. The anti-foundationalism of pragmatism is on the verge of being assimilated into a foundationalism and can easily lose its purchase for critical thinking. To enable Dewey's pragmatism more thoroughly and robustly to resist the tide of the globalized economy, to avoid Democracy and Education being coopted in service of superficial notions of utility, and to promote a different conception of education, it is necessary to keep crossing the borders of dualisms and to sustain the real power of "courageous intelligence." This challenging task calls for "reconstruction in philosophy" [19] as Dewey himself saw, and a reconstruction of his own pragmatism.

A key to such reconstruction can be found in his own language of problem solving. In order to think in and for life, Dewey's thinking in problem solving puts an emphasis on situation-and, in particular, on the "perplexing situation" [1] (pp. 163-164, 185) in which a "genuine problem" is a stimulus to thought [1] (p. 170). In the real difficulties posed by life, Dewey indicates a realm of thinking beyond clarity and transparency: "the twilight zone of inquiry, of thinking, exists" [1] (p. 155, my italics). This is a dimension of intelligence that is derived from within Dewey's thinking in problem solving, and it pushes beyond its own limits.

The idea of the twilight and the related concept of the obscure are abiding themes of classical pragmatism. As Joan Richardson puts this, Peirce pays attention to the light that is hidden below the fringe of the world [20] (p. 67) and recognizes the difficulty of expressing the relation of the amount of the unknown and the known [20] (p. 70). In Experience and Nature (1925), Dewey writes: "It is important for philosophic theory to be aware that the distinct and evident are prized and why they are. But it is equally important to note that the dark and twilight abound. For in any object of primary experience there are always potentialities which are not explicit; any object that is overt is charged with possible consequences that are hidden" [16] (p. 28). Likewise, in Human Nature and Conduct (1922), Dewey refers to the limits of human intelligence: "The goal, the idea is infinite; man is finite" [11] (p. 198); "[humility] is the sense of our slight inability even with our best intelligence and effort to command events" [11] (p. 200). In "Qualitative Thought", Dewey discusses the qualitative whole as the background of thinking, as "the directive clue in what we do expressly think of" [21] (p. 248).

Dewey's idea of twilight suggests a potential to go beyond the dichotomy between the clarity of enlightenment and darkness as a lack of knowledge. It is different both from Plato's light, which enlightens people in the Cave and draws them upwards towards the sun, and from the light of clarity in analytical philosophy.Wittgenstein says, "Nothing is hidden" [22]. However, this does not mean that we can see everything. Rather, he indicates that the reality of the world and the truth of the matter cannot be fully elucidated under light. If obscurity is non-presence, light is non-mediated directness, casting light on something (to be revealed) and something to be hidden. To say something involves what is not said, what is hidden. To foreground something suggests another background. Stanley Cavell speaks of the raising of words, up "to the light" [23] (p. 28). This rediscovery of words is closely related to the idea of aletheia - the idea of revealing, and of acknowledging the hidden as a background [24] (pp. 79, 176). In Dewey's recognition of the limits of intelligence, he indicates the nature of partial light:

At most intelligence but throws a spotlight on that little part of the whole which marks out the axis of movement. Even if the light is flickering and the illuminated portion stands forth only dimly from the shadowy background, it suffices if we are shown the way to move [11] (p. 180).

Here he indicates that the revealing of the world is closely related to the gradual finding of the way-being provisional and non-permanent, like the work of the foresters. 
If we think clearly about clarity, we realize that it must involve a proper (or appropriate) distribution of light and shade. We depend upon shade, the dark, the half-light. In English, "twilight" usually connotes the half-light of the evening. Etymologically speaking "twi-" means between. "Twi-light" suggests a border, between light and dark. The twilight suggests sustaining an antifoundationalism that neither fully abrogates grounding nor fully relies on secure grounding. It indicates how Dewey's thinking might resist the clear light of empiricism and the terms of a globalized economy that dominate thinking in education. The challenging questions then posed to his own pragmatism are: How can we fully live in the obscure twilight of mind and body, of inner and outer? How can then we explore the realm beyond the anti-, to exercise the full force of courageous intelligence? These are crucial, deep questions entailed by thinking beyond problem solving, for the sake of sustaining Dewey's idea of growth as human transformation beyond economic growth.

\subsection{From Democracy and Education to Art as Experience}

Beauty is truth, truth beauty-that is all

Ye know on earth, and all y need to know.

—Keats quoted by Dewey [5] (p. 40)

In response to these questions involving the how, Dewey's Art as Experience (1934) offers a promising response. It points to the art of living in the twilight of inquiry and of crossing borders. Aesthetic experience is not a property of professional artists, but is at the heart of human experience. The idea of ongoing growth accentuates perfectionist elements in Democracy and Education. Aesthetic experience is "the ever-recurring cycles of growth" [5] (p. 152), and this implies a process of "continuing perfecting" [5] (p. 177). Dewey expresses the sense of being on the "growing edge of things" [5] (p. 149), where the artist is a forerunner who carries forward a new vision. From time to time, Dewey describes the moment of what might be called being on a threshold in the "twilight" [5] (p. 198), where "ordinary boundaries are transformed into invitations to proceed" [5] (p. 213), with the anticipation of a new horizon ahead. Here is expressed the sense that each of us, as an artist, is standing on tiptoe, exposed to this ongoing movement of attaining "consistency" and "security" [5] (p. 63).

Dewey characterizes aesthetic experience as involving "happiness and delight", related to a "fulfillment that reaches to the depth of our being" [5] (p. 23). Art has to do with the "intensity" and immediacy of the moment, of "what now is" [5] (p. 24), and the experience of "direct seizure" [5] (p. 150). Here Dewey highlights the role of the receptive dimension of experience typified in "esthetic surrender" [5] (pp. 35, 51, 108). All of this requires the interrelated working of perception, which is to be understood as "an act of the going-out of energy in order to receive, not withholding of energy" [5] (p. 60). This is the art of living here and now, standing on the border, on the growing edge of things.

In reference to Matthew Arnold, Dewey calls poetry "criticism of life" (Arnold is quoted in [5] p. 349). Dewey highlights the role of aesthetic judgment as a source of social and cultural criticism (AE, p. 328). Shifting the tone of problem solving away from the social intelligence that was more prominent in Democracy and Education, Dewey renews his emphasis on the significance of "a bias, a predilection" and encourages us not to surrender "the instinctive preference" [5] (p. 327). He also touches upon the necessity of the cultivation of aesthetic imagination. The imagination typically exercised by an artist is the "precursor of the changes" [5] (p. 348). Through the power of "imaginative projection" and as "the moral prophets of humanity", poets become "the founders of civil society" [5] (p. 350). Such an aesthetic concept of intelligence is what Dewey calls "creative intelligence" (AE, p. 351). The aesthetic imagination is necessary in order to dive into the realm beyond the problem solving, towards the realm of the unknown, the realm yet-to-be created. He recognizes the significance of "obscurity" in Shakespeare and Coleridge, and of "half-knowledge" in Keats [5] (p. 39). In exceeding the limits of existing frameworks of thinking, in order to see what otherwise cannot be seen, creative intelligence must be courageous and adventurous. 


\section{Towards an Economy of Beautiful Knowledge}

When the future arrives with its inevitable disappointments as well as fulfillments, and with new sources of trouble, failure loses something of its fatality, and suffering yields fruit of instruction not of bitterness. Humility is more demanded at our moments of triumph than at those of failure [11] (p. 200).

Pragmatism is the philosophy of chance [14,25]. The globalized economy provides an opportunity, even the requirement, for a turning point in thinking - to think again what knowledge is useful and how to live a better life. For the critical reconstruction of pragmatism beyond its limits, there is more to say about the alternative dimension of thinking and knowledge that Dewey offers in Art as Experience. For us to think fully in the twilight of inquiry means to confront the limits of our knowledge. We are posed with the threat of skepticism and the sense of the tragic. Putnam suggests that pragmatism is antiskepticist [26] (p. 68): Bernstein says that pragmatism exorcises skepticism [27] (p. 19). However, to read Dewey's antifoundationalism and antidualism in a way that is robust enough to resist the pressures of a globalized economy, in its tendency to cover over the tragic sense and the anxiety of human existence in apparent transparency and clarity, we must delve into the territory of skepticism, further into the twilight of inquiry. In acknowledging the limits of pragmatism in this sense, and standing at an entrance into such further inquiry, the point of this paper is to indicate, at least, the potential hidden within Dewey's thinking in problem solving: to make the best use of Dewey's pragmatism in order to live with and beyond the terms of a globalized economy. In order to revive the philosophy for praxis, I would like, in conclusion, to envision a different conception of education.

One of the best and most useful wisdoms to be drawn from Art as Experience is its reminder that there is a dimension in the functional that cannot be simply assimilated into the practical goal or reduced to accountable and empirical evidence. Going beyond the dichotomy of the beautiful and the sublime, and between the aesthetic and the functional, Dewey's pragmatism can turn us towards aesthetic and religious experience of rebirth in the ordinary-the manifestation of higher intelligence in the low and the common. It is Thoreau's idea of Beautiful Knowledge that serves as a reference point by way of which to explain further the implications of this insight of Dewey. Thoreau writes:

To be a philosopher is not merely to have subtle thoughts, nor even to found a school, but so to love wisdom as to live according to its dictates, a life of simplicity, independence, magnanimity, and trust. It is to solve some of the problems of life, not only theoretically but practically [28] (p. 9).

Integrating body, mind, and language, and doing this more robustly than Dewey, Thoreau redeems the economy of living, in what he calls "higher knowledge" or "Sympathy with Intelligence" [6] (p. 113).

We have heard of a Society for the Diffusion of Useful Knowledge. It is said that knowledge is power; and the like. Methinks there is equal need of a Society for the Diffusion of Useful Ignorance, what we will call Beautiful Knowledge, a knowledge useful in a higher sense [6] (p. 112).

This reminds us of the Socratic idea of ignorance, and yet, in Thoreau's case, and in American philosophy in general, an emphasis is put more on praxis—on the common and on daily experience, as exemplified by Thoreau's labor in the bean field at Walden. It is only through such down-to-earth practice that the moment of rebirth, what may be called transcendence in the ordinary, occurs. Beautiful Knowledge is anything but the object of a direct perception under clear sunlight. As it cannot be obtained in the glare of sunlight, it is important that it is not anticipated in the form of direct, immediate knowledge-under "an excess even of informing light" [6] (p. 111). Being "transformational rather than informative" [29] (p. 78), Beautiful Knowledge is not the target of learning or the product of direct 
acquisition, but something that is experienced in the re-vising of the necessities of life. Dewey's Art as Experience at least points us to such Beautiful Knowledge.

Beautiful Knowledge can be used as the means towards a different conception of economy, where there is retrieved an earlier sense of this word that carries the ordering of one's way of living, one's home-that is, in an "economy of living" [30] (p. 234). It is with this sense that Paul Standish has written of the "economy of higher education" [24] (p. 561). The idea of "higher" here is not intended to suggest primarily abstract or highbrow knowledge. Rather, it is the experience of what might be called a "transcendence down" [31] (p. 25). The beautiful, Thoreau says, is inseparable from the wild and apparently unbeautiful. Thoreau associates it with the "most dismal swamp" in the darkest wood [6] (p. 100), which he calls the "sanctum sanctorum" [6]. Beautiful Knowledge, as "wild and dusky" [6] (p. 112) is not the preserve of self-conscious literary refinement, but it is to be found in classic texts:

It is the uncivilized free and wild thinking in "Hamlet" and the "Illiad," in all the Scirptures and Mythologies, not learned in the schools, that delights us. As the wild duck is more swift and beautiful than the tame, so is the wild—-the mallard—-thought, which 'mid falling dews wings its way above the fens' [6] (pp. 102-103).

Beyond the dichotomy of the natural (the wild) and the human (the civilized), and far from intellectualism and anti-intellectualism, Thoreau proposes that we regain the untamed, self-reliant power of thinking and reading as a distinctive capacity of the human. This is the education for the wild duck, not for excellent sheep.

This points to the kind of educative experience that can be found especially in the humanities class and beyond, in natural and social scientific inquiry that is fused with human values [32], and in the cultivating of aesthetic imagination in art, literature, and music. An interdisciplinary curriculum in the pragmatist spirit, where borders are crossed, will not simply combine science with the humanities: it is rather that learners in each discipline experience, through interaction, the destabilization of mutual standpoints; they acquire the ability to think on the borders, to cross boundaries. This may involve the experience of translating the currency of language in one discipline into that of another, and yet it will also entail the experience of incommensurability and disparity, where ways of reasoning may be complementary but may at times conflict with one another. In this respect it does make sense for higher education to open its doors to the larger society including to industry in new ways, but without merely subjugating itself to the requirements of the globalized economy. It must still be the site for the cultivation of Man Thinking, for cultivating the art of the criticism of criticisms. As a never ending process of perfection, such higher education is continuing education. It becomes philosophy as the education of grownups $[33,34]$.

Conflicts of Interest: The author declares no conflict of interest.

\section{References and Notes}

1. Dewey, J. Democracy and Education (1916). In The Middle Works of John Dewey; Boydston, J.A., Ed.; Southern Illinois University Press: Carbondale, IL, USA, 1980; Volume 9.

2. Deresiewicz, W. Excellent Sheep: The Miseducation of the American Elite and the Way to a Meaningful Life; Free Press: New York, NY, USA, 2014.

3. Dewey, J. Creative Democracy-The Task Before Us (1939). In The Later Works of John Dewey; Boydston, J.A., Ed.; Southern Illinois University Press: Carbondale, IL, USA, 1988; Volume 14.

4. Bernstein, R. The Pragmatic Turn; Polity Press: Cambridge, MA, USA, 2010.

5. Dewey, J. Art as Experience (1934). In The Later Works of John Dewey; Boydston, J.A., Ed.; Southern Illinois University Press: Carbondale, IL, USA, 1987; Volume 10.

6. Thoreau, H.D. Walking. In Nature/ Ralph Waldo Emerson, Walking/ Henry David Thoreau; Beacon Press: Boston, MA, USA, 1991; pp. 69-122.

7. Mordechai, G.; Andrea, R.E. Introduction: John Dewey's Democracy and Education in an Era of Globalization. Educ. Philos. Theory 2016, 48, 977-980. 
8. Bernstein, R. The Resurgence of Pragmatism. Soc. Res. 1992, 59, 813-840.

9. Bernstein, R.J. Global Resurgence of Pragmatism. (Keynote speech at the special session, "American Philosophy in Cross-Cultural Dialogue: Conversations with Richard Bernstein," organized by Supporting Program for Interaction-based Initiative Team Studies [SPIRITS] at Kyoto University co-organized with the American Philosophy Forum of Japan, Saturday 11 June 2016, Kyoto University).

10. Bernstein, R.J. Response to Naoko Saito. (Response to Naoko Saito's paper, “American Philosophy in Translation, at the special session, "American Philosophy in Cross-Cultural Dialogue: Conversations with Richard Bernstein," organized by Supporting Program for Interaction-based Initiative Team Studies [SPIRITS] at Kyoto University co-organized with the American Philosophy Forum of Japan, Saturday 11 June 2016, Kyoto University).

11. Dewey, J. Human Nature and Conduct (1922). In The Middle Works of John Dewey; Boydston, J.A., Ed.; Southern Illinois University Press: Carbondale, IL, USA, 1983; Volume 14.

12. Comment by Bernstein at a meeting on 13 June 2016, Kyoto University.

13. Putnam, H. The Founders of Pragmatism on Philosophy and Life. (Skype lecture at the conference, "Philosophy as Translation and Understanding Other Cultures," Kyoto University, Supporting Program for Interaction-based Initiative Team Studies [SPIRITS], 6 July 2014, Kyoto University).

14. Saito, N. Taking a Chance: Education for Aesthetic Judgment and Cultural Criticism. Ethics Educ. 2015, 10, 96-104.

15. Emerson, R.W. The Essential Writings of Ralph Waldo Emerson; Brooks, A., Ed.; The Modern Library: New York, NY, USA, 2000.

16. Dewey, J. Experience and Nature (1925). In The Later Works of John Dewey; Boydston, J.A., Ed.; Southern Illinois University Press: Carbondale, IL, USA, 1981; Volume 1.

17. Putnam, H. Ethics without Ontology; Harvard University Press: Cambridge, MA, USA, 2004.

18. Dewey, J. Construction and Criticism (1930). In The Later Works of John Dewey; Boydston, J.A., Ed.; Southern Illinois University Press: Carbondale, IL, USA, 1984; Volume 5, pp. 127-143.

19. Dewey, J. Reconstruction in Philosophy; Beacon Press: Boston, MA, USA, 1920.

20. Richardson, J. Pragmatism and American Experience: An Introduction; Cambridge University Press: Cambridge, UK, 2014.

21. Dewey, J. Qualitative Thought (1930). In The Later Works of John Dewey; Boydston, J.A., Ed.; Southern Illinois University Press: Carbondale, IL, USA, 1984; Volume 5, pp. 243-266.

22. Wittgenstein, L. Philosophical Investigations; Wiley-Blackwell: Oxford, UK, 2009.

23. Cavell, S. The Senses of Walden; The University of Chicago Press: Chicago, IL, USA, 1992.

24. Standish, P. Beyond the Self: Wittgenstein, Heidegger, Levinas and the limits of language; Saito, N., Translator; Hosei University Press: Tokyo, Japan, 2012. (In Japanese)

25. Saito, N. American Philosophy and its Eastern Strains: Crisis, Resilience, and Self-Transcendence. Educ. Philos. Theory 2016, 48, 1065-1076. [CrossRef]

26. Putnam, H. Pragmatism: Open Question; Blackwell: Oxford, UK, 1995.

27. Bernstein, R.J. Beyond Objectivism and Relativism: Science, Hermeneutics, and Praxis; University of Pennsylvania Press: Philadelphia, PA, USA, 1983.

28. Thoreau, H.D. Walden and Resistance to Civil Government; Willliam, R., Ed.; W. W. Norton \& Company: New York, NY, USA, 1992.

29. Standish, P. Social Justice in Translation: Subjectivity: Identity, and Occidentalism. Educ. Stud. Jpn. Int. Yearb. 2011, 6, 69-79.

30. Standish, P.; Saito, N. Stanley Cavell's Walden: An Introduction for the Japanese Reader. In The Senses of Walden; Saito, N., Translator; Hosei University Press: Tokyo, Japan, 2005; pp. 213-240. (In Japanese)

31. Standish, P. Pure Experience and Transcendence down. In Education and the Kyoto School of Philosophy: Pedagogy for Human Transformation; Paul, S., Saito, N., Eds.; Springer: Dordrecht, The Netherlands, 2012; pp. 19-26.

32. Putnam, H. Philosophy in an Age of Science: Physics, Mathematics, and Skepticism; Mario, D.C., David, M., Eds.; Harvard University Press: Cambridge, MA, USA, 2012. 
33. Cavell, S. The Claim of Reason: Wittgenstein, Skepticism, Morality, and Tragedy; Oxford University Press: Oxford, UK, 1979.

34. Saito, N.; Standish, P. (Eds.) Stanley Cavell and the Education of Grownups; Fordham University Press: New York, NY, USA, 2012. 